\title{
Iron encrustations on filamentous algae colonized by Gallionella-related bacteria in a metal-polluted freshwater stream
}

\author{
J. F. Mori ${ }^{1}$, T. R. Neu ${ }^{2}$, S. Lu ${ }^{1,3}$, M. Händel ${ }^{4}$, K. U. Totsche ${ }^{4}$, and K. Küsel ${ }^{1,3}$ \\ ${ }^{1}$ Institute of Ecology, Aquatic Geomicrobiology, Friedrich Schiller University Jena, Dornburger Strasse 159, \\ 07743 Jena, Germany \\ ${ }^{2}$ Department of River Ecology, Helmholtz Centre for Environmental Research - UFZ, Brueckstrasse 3A, \\ 39114 Magdeburg, Germany \\ ${ }^{3}$ German Centre for Integrative Biodiversity Research (iDiv) Halle-Jena-Leipzig, Deutscher Platz 5e, \\ 04103 Leipzig, Germany \\ ${ }^{4}$ Institute of Geosciences, Hydrogeology, Friedrich Schiller University Jena, Burgweg 11, 07749 Jena, Germany
}

Correspondence to: K. Küsel (kirsten.kuesel@uni-jena.de)

Received: 17 April 2015 - Published in Biogeosciences Discuss.: 22 May 2015

Accepted: 28 August 2015 - Published: 16 September 2015

\begin{abstract}
Filamentous macroscopic algae were observed in slightly acidic to circumneutral ( $\mathrm{pH}$ 5.9-6.5), metal-rich stream water that leaked out from a former uranium mining district (Ronneburg, Germany). These algae differed in color and morphology and were encrusted with $\mathrm{Fe}$ deposits. To elucidate their potential interaction with $\mathrm{Fe}$ (II)oxidizing bacteria $(\mathrm{FeOB})$, we collected algal samples at three time points during summer 2013 and studied the algaebacteria-mineral compositions via confocal laser scanning microscopy (CLSM), scanning electron microscopy (SEM), Fourier transform infrared (FTIR) spectra, and a $16 \mathrm{~S}$ and 18S rRNA gene-based bacterial and algae community analysis. Surprisingly, sequencing analysis of $18 \mathrm{~S}$ rRNA gene regions of green and brown algae revealed high homologies with the freshwater algae Tribonema (99.9-100\%). CLSM imaging indicated a loss of active chloroplasts in the algae cells, which may be responsible for the change in color in Tribonema. Fe(III)-precipitates on algal cells identified as ferrihydrite and schwertmannite by FTIR were associated with microbes and extracellular polymeric substances (EPS)like glycoconjugates. SEM imaging revealed that while the green algae were fully encrusted with Fe-precipitates, the brown algae often exhibited discontinuous series of precipitates. This pattern was likely due to the intercalary growth of algal filaments which allowed them to avoid detrimental encrustation. 16S rRNA gene-targeted studies revealed
\end{abstract}

that Gallionella-related FeOB dominated the bacterial RNA and DNA communities (70-97 and 63-96\%, respectively), suggesting their capacity to compete with the abiotic $\mathrm{Fe}$ oxidation under the putative oxygen-saturated conditions that occur in association with photosynthetic algae. Quantitative PCR (polymerase chain reaction) revealed even higher Gallionella-related 16S rRNA gene copy numbers on the surface of green algae compared to the brown algae. The latter harbored a higher microbial diversity, including some putative predators of algae. A loss of chloroplasts in the brown algae could have led to lower photosynthetic activities and reduced EPS production, which is known to affect predator colonization. Collectively, our results suggest the coexistence of oxygen-generating algae Tribonema sp. and strictly microaerophilic neutrophilic FeOB in a heavy metal-rich environment.

\section{Introduction}

Algae are known to inhabit all freshwater ecosystems including rivers, streams, lakes, and even small water volumes present in pitcher plants (Stevenson et al., 1996; Cantonati and Lowe, 2014; Gebühr et al., 2006). Macroscopic algae often bloom rapidly in rivers and in small freshwater streams, such as groundwater effluents (Stevenson et al., 
1996), through germination of spores, vegetative growth, and reproduction (Transeau, 1916). As primary producers, these algae provide benefits for other organisms by supplying them with organic matter and oxygen via photosynthesis and are often surrounded by associated microbes (Haack and McFeters, 1982; Geesey et al., 1978; Cole, 1982; Azam, 1998). Unicellular and multicellular algae can produce polysaccharides like extracellular polymeric substances (EPS) as a shunt for carbon produced in excess during photosynthesis (Wotton, 2004; Liu and Buskey, 2000). Due to these functions, algae likely affect the activities of coexisting microbes and play important roles in the microbial ecology of streams.

Some algal species have been detected in metal-polluted streams, such as hot spring effluents (Wiegert and Mitchell, 1973) and mining-impacted sites (Reed and Gadd, 1989; Warner, 1971). These algae are known to be tolerant or resistant to high concentrations of metals such as $\mathrm{Zn}, \mathrm{Cu}, \mathrm{Cd}$, $\mathrm{Pb}, \mathrm{Fe}$, and As (Reed and Gadd, 1989; Foster, 1977, 1982), and some are capable of accumulating metals (Fisher et al., 1998; Yu et al., 1999; Greene et al., 1987) which makes them ideal candidates for bio-remediation of metal-polluted sites (Yu et al., 1999; Malik, 2004). Green algae, such as Ulothrix, Microspora, Klebsormidium, and Tribonema, occur in acid mine drainage (AMD)-impacted sites (Warner, 1971; Winterbourn et al., 2000; Das et al., 2009), sometimes forming heterogeneous streamer communities (Rowe et al., 2007). Although some of these algae show iron ocher depositions, their interactions with $\mathrm{Fe}(\mathrm{II})$-oxidizing bacteria are not well characterized.

A group of prokaryotes called $\mathrm{Fe}(\mathrm{II})$-oxidizing bacteria (FeOB) mediates the oxidation of Fe(II) to Fe(III) to conserve energy for growth (Colmer and Hinkle, 1947; Hanert, 2006). Most FeOB are autotrophs (Johnson and Hallberg, 2009; Kappler and Straub, 2005). Biogenic Fe(III) subsequently hydrolyzes and precipitates from solutions, forming various $\mathrm{Fe}$ (III)-oxides when the $\mathrm{pH}$ exceeds 2 (Johnson et al., 2014). Aerobic acidophilic Fe(II)-oxidizers are the main drivers of $\mathrm{Fe}$ (II)-oxidation in acidic and iron-rich freshwater environments due to low rates of chemical Fe(II)-oxidation under acidic conditions (Leduc and Ferroni, 1994; Hallberg et al., 2006; Tyson et al., 2004; López-Archilla et al., 2001; Senko et al., 2008; Kozubal et al., 2012). In contrast, neutrophilic FeOB, such as Gallionella spp., Sideroxydans spp., or Leptothrix spp., have to compete with a rapid chemical $\mathrm{Fe}(\mathrm{II})$-oxidation at circumneutral $\mathrm{pH}$ and thus often inhabit oxic-anoxic transition zones, such as sediment-water surfaces (Emerson and Moyer, 1997; Peine et al., 2000; Hedrich et al., 2011b) or the rhizosphere of wetland plants, where the plant roots leak oxygen and $\mathrm{FeOB}$ deposit Fe-minerals (known as "Fe-plaques") on plant root surfaces (Neubauer et al., 2002; Johnsongreen and Crowder, 1991; Emerson et al., 1999). Gallionella spp. are chemolithoautotrophs that prefer microoxic conditions (Emerson and Weiss, 2004; Lüdecke et al., 2010).
We observed macroscopic streamer-forming algae in slightly acidic to circumneutral ( $\mathrm{pH}$ 5.9-6.5), metal-rich stream water flowing out of passively flooded abandoned underground mine shafts in the former Ronneburg uranium mining district in Germany. This seeping groundwater creates new streams and iron-rich terraces at an adjacent drainage creek bank. The filamentous algae present during the summer months differed mainly in color, but all types showed iron ocher deposits. Since high abundances of Gallionella-related $\mathrm{FeOB}$ were detected in the seeping water and the drainage creek in previous studies (Fabisch et al., 2013, 2015), potential interactions between these neutrophilic $\mathrm{FeOB}$ and the streamer-forming algae communities were suggested.

Few studies have addressed the relationship between $\mathrm{Fe}(\mathrm{II})$-oxidation and algae. A previous study reported that oxygen production by cyanobacteria appeared to control $\mathrm{Fe}(\mathrm{II})$-oxidation in iron-rich microbial mats at Chocolate Pots in Yellowstone, despite the co-existence of anoxygenic photosynthetic FeOB (Trouwborst et al., 2007), but there was no evidence of biogenic $\mathrm{Fe}(\mathrm{II})$-oxidation by chemolithotrophic neutrophilic FeOB. Another study examining a bicarbonate $\mathrm{Fe}(\mathrm{II})$-rich spring in the Swiss Alps showed the co-existence, but physical separation, of cyanobacteria and Gallionellaceae (Hegler et al., 2012). Since the presence and activity of neutrophilic FeOB close to oxygen-generating photosynthetic organisms has not been documented, we applied different microscopic techniques to localize the Fe-minerals and microorganisms on the algal surfaces and compared the bacterial community structure of different algal samples to learn more about these multispecies interactions in metal-polluted environments.

\section{Materials and methods}

\subsection{Field site and sampling}

Algal samples were taken in the outflow water in the former Ronneburg uranium mining district (Thuringia, Germany) in 2013. This district in eastern Germany was one of the largest uranium mining operations in the world which produced 113000 metric tons of uranium primarily through heap-leaching with sulfuric acid between 1945 and German reunification in 1990. After the mines were closed, the open pit was filled with waste rock from the leaching heaps to prevent further acid mine drainage (AMD). The underground mines were flooded and treated with alkali to buffer the water to a more neutral $\mathrm{pH}$. The mine-water outflow began in 2010 when the water table rose and contaminated water from the underground mine reached the surface of surrounding grassland. The mine-water outflow flowed $20 \mathrm{~m}$ down a hillside into the creek (Fig. 1) where red-orange terraces enriched with the Fe-oxyhydroxides goethite and ferrihydrite formed (Johnson et al., 2014; Fabisch et al., 2015). 


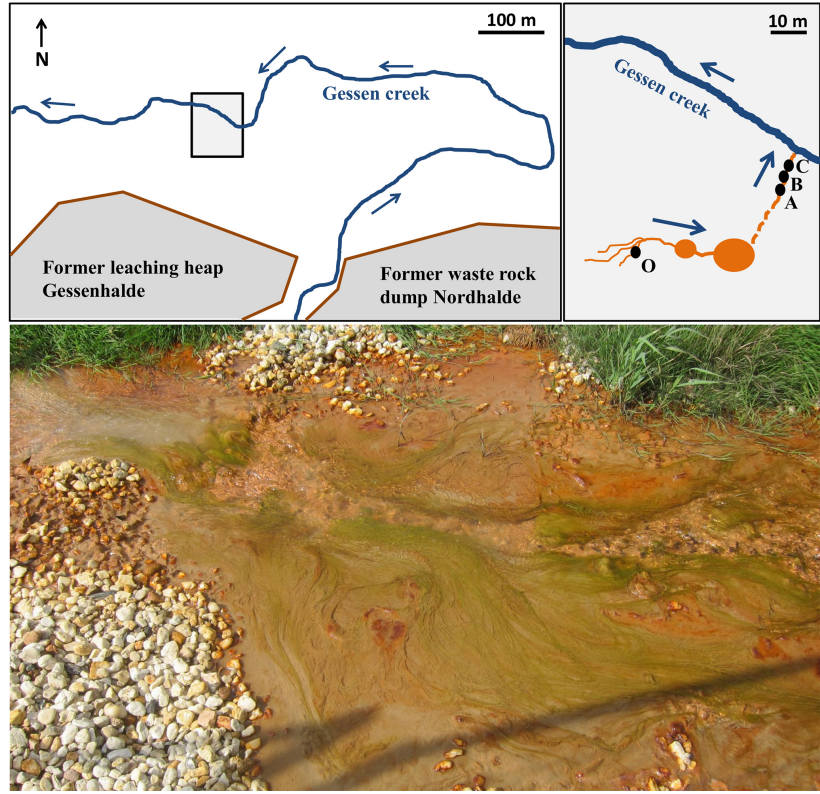

Figure 1. Schematic maps of the study site and photograph of site A in the former Ronneburg uranium mining district (Thuringia, Germany). Maps show the locations of sampling sites $\mathrm{O}, \mathrm{A}, \mathrm{B}$, and $\mathrm{C}$ on the grassland close to Gessen creek. Blue arrows indicate the flow direction of the creek and outflow streams. The photograph was taken in September 2011 and shows the presence of conspicuous green filamentous algae.

We sampled algae of green and brown color in July, August, and September from four different sites, beginning at the outflow water (site $\mathrm{O}$ ) and three sites further downstream $(\mathrm{A}, \mathrm{B}, \mathrm{C})$ which were separated from $\mathrm{O}$ by some artificial impoundments; the distance between $\mathrm{A}$ and $\mathrm{C}$ was $8.8 \mathrm{~m}$ (Fig. 1). In July 2013, we could not reach site O because it was fenced off due to construction work. Chemical parameters of water $(\mathrm{pH}$, temperature, Eh, and oxygen concentration) were measured in situ at every sampling time, using relevant electrodes and meters (Mettler Toledo; WTW, Switzerland). In addition, water collected from each site was filtered with $0.45 \mu \mathrm{m}$ polyvinylidene fluoride (PVDF) and acidified with $\mathrm{HCl}$ or $\mathrm{HNO}_{3}$ on-site and stored at $4{ }^{\circ} \mathrm{C}$ until the measurements of metals, sulfate, and dissolved organic carbon (DOC) concentrations were made. Algae and sediment samples were taken from the stream with a sterilized spatula and stored at $4{ }^{\circ} \mathrm{C}$ for microscopic analyses or at $-80^{\circ} \mathrm{C}$ for molecular biological experiments, respectively.

\subsection{Geochemical characterization of the stream}

Concentration of $\mathrm{Fe}(\mathrm{II})$ in water was detected using the phenanthroline method (Tamura et al., 1974) and total Fe was determined following the addition of ascorbic acid $(0.6 \%$ final concentration). Sulfate concentration was determined using the barium chloride method (Tabatabai, 1974). DOC in water was measured by catalytic combustion oxidation us- ing a TOC analyzer (TOC-V CPN, Shimadzu, Japan). Dissolved metals ( $\mathrm{Fe}, \mathrm{Mn}, \mathrm{Ni}$, and $\mathrm{U}$ ) in stream water were measured using inductively coupled plasma mass spectrometry (ICP-MS; X-Series II, Quadrupole, Thermo Electron, Germany). Metals which accumulated on the sediments and the algae were determined by ICP-MS and ICP optical emission spectrometry (ICP-OES, 725ES, Varian, Germany) after digestion. The algae sample taken at site $\mathrm{C}$ in August 2013 and stored at $4{ }^{\circ} \mathrm{C}$ was washed with deionized water on a petri dish to remove big sediment particles, which was then followed by drying $\left(200^{\circ} \mathrm{C}\right.$, overnight), grinding, and microwave digestion (Mars XPress, CEM, Germany) using $\mathrm{HNO}_{3}$ for ICP-MS/OES measurements. The sediment samples taken at each sampling site were also dried and ground, and then $0.1-0.5 \mathrm{~g}$ of sediments were digested using $2 \mathrm{~mL}$ $\mathrm{HNO}_{3}, 3 \mathrm{~mL} \mathrm{HF}$, and $3 \mathrm{~mL} \mathrm{HClO}_{4}$ for ICP-MS/OES measurements.

\subsection{Observation of algae under light microscope}

The fresh algal samples were observed on the same day as sampling under light microscope (Axioplan, Zeiss, Germany). Small pieces $(\sim 5 \mathrm{~mm})$ of algal bundles were picked, placed on a glass slide with small amount of stream water, and then covered with a glass coverslip. Microscopic images were taken with digital camera ProgRes CS (Jenoptik, Germany) in a bright field.

\subsection{CLSM imaging}

The algal samples collected in September were examined by confocal laser scanning microscopy (CLSM) using a TCS SP5X (Leica, Germany). The upright microscope was equipped with a white laser source and controlled by the software LAS AF, version 2.4.1. Samples were mounted in a $0.5 \mu \mathrm{m}$ deep CoverWell ${ }^{\mathrm{TM}}$ (Lifetechnologies) chamber and examined with a $63 \times$ NA 1.2 water immersion lens. Algal-associated bacteria were stained with $\mathrm{SYTO}^{\circledR}$ 9, a nucleic acid specific fluorochrome. Fluorescently labeled lectin (AAL-Alexa448, Linaris), which preferentially binds to fucose, linked $\alpha-1,6$ to $N$-acetylglucosamine or $\alpha-1,3$ to $N$ acetyllactosamine-related structures, which can be applied for the detection of algal cell walls (Sengbusch and Müller, 1983) and the microbial EPS complex (Neu et al., 2001), was used to stain and detect glycoconjugates. The recording parameters were as follows: excitation at laser lines 488, 568, $633 \mathrm{~nm}$; emissions recorded at 483-493 (reflection), 500550 (SYTO ${ }^{\circledR} 9$ ), 580-620 (possible autofluorescence), and 650-720 (chlorophyll $a$ ). Optical sections were collected in the $\mathrm{Z}$ direction with a step of $1 \mu \mathrm{m}$. Images were deconvolved using the option "classic maximum likelihood estimation" from Huygens, version 14.06 (SVI). Lastly, image data sets were projected by Imaris, version 7.7.2 (Bitplane). 


\subsection{SEM-EDX}

Scanning electron microscopy (SEM) was used to study the morphology of mineral precipitates on algal surfaces. Droplets of sample suspensions were placed on silicon wafers and subjected to air drying. High-resolution secondary electron (SE) images and energy dispersive X-ray spectroscopy (EDX) were taken with an ULTRA plus field emission scanning electron microscope (Zeiss).

\subsection{FTIR measurement for mineral precipitates on algae}

Fourier transform infrared (FTIR) spectra of algae encrusted with Fe-minerals were recorded using a Nicolet iS10 spectrometer (Thermo Fisher Scientific, Dreieich, Germany). Mortared samples were mixed with $\mathrm{KBr}$ (FTIR grade, Merck, Darmstadt, Germany) at a ratio of $1: 100$ and pressed into pellets. The pellets were studied in transmission mode in the mid-infrared range between 4000 and $400 \mathrm{~cm}^{-1}$ for a total of 16 scans at a resolution of $4 \mathrm{~cm}^{-1}$. Spectra were baseline-corrected by subtracting a straight line running between the two minima of each spectrum and normalized by dividing each point by the spectrum's maximum.

\subsection{Total nucleic acids extraction from algae-microbial communities}

Total nucleic acids of algae-microbial communities were extracted from $\sim 1.4 \mathrm{~g}$ wet weight of algal bundle via bead beating in $\mathrm{NaPO}_{4}$ buffer $(\mathrm{pH}$ 8.0) with TNS solution $(500 \mathrm{mM}$ Tris- $\mathrm{HCl} \mathrm{pH} 8.0,100 \mathrm{mM} \mathrm{NaCl}, 10 \%$ SDS wt $\left.\mathrm{vol}^{-1}\right)$. The supernatant was taken after centrifugation, followed by extraction with equal volumes of phenolchloroform-isoamyl alcohol [PCI, $25: 24: 1$ (vol : vol : vol), AppliChem] and chloroform-isoamyl alcohol [CI, 24:1 (vol : vol), AppliChem]. Nucleic acids were precipitated with two volumes of polyethylene glycol (PEG) by centrifugation at $20000 \mathrm{~g}$ and $4{ }^{\circ} \mathrm{C}$ for $90 \mathrm{~min}$. The pellets were washed with ice-cold $70 \%$ ethanol and suspended in $50 \mu \mathrm{L}$ elution buffer (EB, Qiagen).

\subsection{S rRNA gene-based identification of algal species}

The 18S rRNA gene region of the DNA extracted from algae-microbial communities was amplified by PCR (polymerase chain reaction) employing the universal primer pair Euk20F/Euk1179R (Euringer and Lueders, 2008) or the Chlorophyta-targeting primer pair P45/P47 (Dorigo et al., 2002). The PCR reactions using both primer pairs were as follows: initial denaturing at $94^{\circ} \mathrm{C}$ for $5 \mathrm{~min}, 25-30$ cycles of denaturing at $94^{\circ} \mathrm{C}$ for $30 \mathrm{~s}$, annealing at $57^{\circ} \mathrm{C}$ for $30 \mathrm{~s}$, and extension at $72^{\circ} \mathrm{C}$ for $90 \mathrm{~s}$, and followed by final extension at $72^{\circ} \mathrm{C}$ for $10 \mathrm{~min}$. Amplified products were purified through a spin column (NucleoSpin Gel and PCR cleanup, Macherey-Nagel, Germany) and sequenced using Sanger technology (Macrogen Europe, Amsterdam, The Netherlands). Sequences were processed using Geneious 4.6.1 for trimming and assembling, followed by the BLAST homology search.

\subsection{Quantitative PCR}

Quantitative PCR was performed to elucidate the 16S rRNA gene copy numbers of Gallionella colonizing the algae surface using 16S rRNA gene-targeted primers specific for Gallionella spp. (Gal122F, 5'-ATA TCG GAA CAT ATC CGG AAG T -3'; Gal384R, 5' - GGT ATG GCT GGA TCA GGC -3'; Heinzel et al., 2009). Aliquots of $1.25 \mathrm{ng}$ DNA were used in triplicate as the template for qPCR using the Mx3000P real-time PCR system (Agilent, USA) and Maxima SYBR Green qPCR Mastermix (Fermentas, Canada). Standard curves were prepared by serial dilution of plasmid DNA containing the cloned 16S rRNA gene sequence of Gallionella (accession no. JX855939). Melting curve analysis was used to confirm the specificities of the qPCR products. PCR grade water and TE buffer were included as nontemplate controls. Detailed qPCR conditions have been described by Fabisch et al. (2013).

\subsection{Amplicon pyrosequencing}

16S rRNA gene-targeted amplicon pyrosequencing was performed to reveal the population structures of bacteria on the algae. To determine the bacterial community composition based on RNA, cDNA samples were prepared as follows: $3.3-6.0 \mu \mathrm{g}$ of total nucleic acids extracted from algae-microbial communities were treated with DNase using TURBO DNA-free ${ }^{\mathrm{TM}}$ Kit (Ambion, USA) to remove all DNA, and then 0.3-0.5 $\mu$ g of DNase-treated RNA samples were transcribed to cDNA using RETROscript ${ }^{\circledR}$ Kit (Life Technologies, CA) and stored at $-20^{\circ} \mathrm{C}$. The total nucleic acid samples (as DNA samples) and cDNA samples were sent to the Research and Testing Laboratory (Lubbock, TX, USA) for pyrosequencing of the V4-V6 region. Samples were sequenced on a Roche 454 FLX system using tags, bar codes, and forward primers; these are listed in Table S1 in the Supplement. Sequence reads were processed in Mothur 1.33.0 (Schloss et al., 2009) for trimming, quality checking, screening, chimera removal, and alignment based on the Silva reference alignment files provided on the Mothur website (http://www.mothur.org/wiki/Silva_reference_files). Dendrograms were constructed in Mothur using unweighted pair group method arithmetic averages (UPGMA) based on the Bray-Curtis index (Bray and Curtis, 1957) to estimate similarity among bacterial DNA and RNA community compositions in each sample. Sequences originating from algal chloroplasts were removed for statistical analysis of community composition. The Gini-Simpson index was calculated using Mothur. 

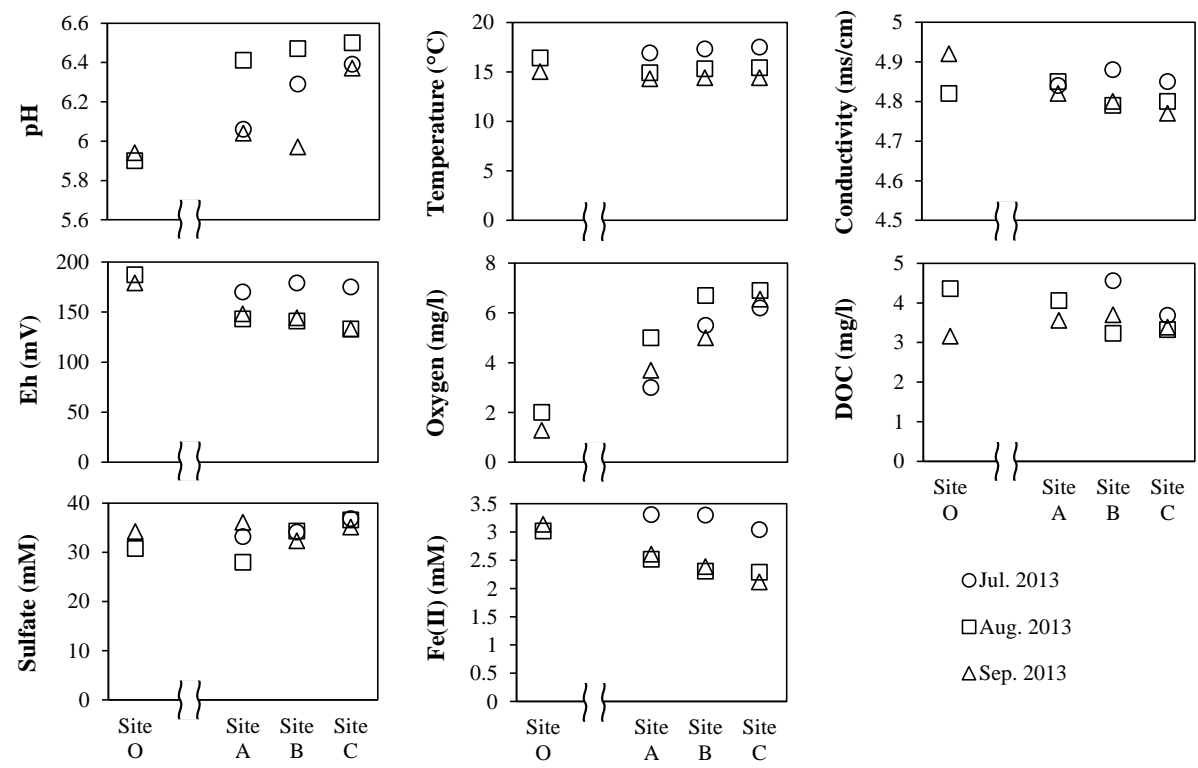

OJul. 2013

$\square$ Aug. 2013

$\triangle$ Sep. 2013

Figure 2. Chemical parameters of water at each sampling site in the outflow water stream. Water pH, oxygen, temperature, conductivity, and Eh were measured in the field at site O, A, B, and C in July, August, and September 2013. Concentrations of organic carbon, sulfate, and $\mathrm{Fe}$ (II) were determined later in the laboratory.
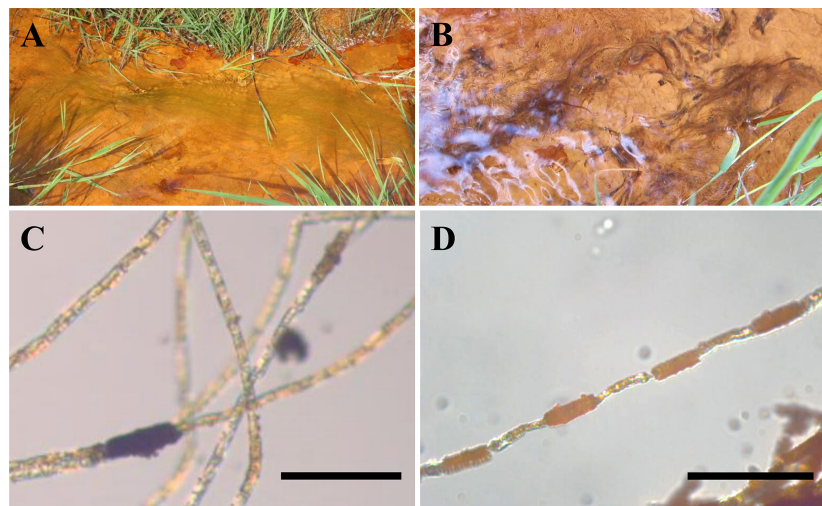

D

Figure 3. Photographs (a, b) and light microscopic pictures (c, d) of the green algae in site $\mathrm{A}(\mathbf{a}, \mathbf{c})$ and the brown algae in site $\mathrm{C}(\mathbf{b}$, d) taken in July 2013. The microscopic pictures show Fe-mineral precipitates on the algae. Scale bars indicate $100 \mu \mathrm{m}$.

\section{Results}

\subsection{Characterization of algae-bacterial assemblage}

Abundant macroscopic filamentous algae up to $10 \mathrm{~cm}$ length appeared at the outflow site $(\mathrm{O}$; Fig. 1) and further downstream at sites $\mathrm{A}, \mathrm{B}$, and $\mathrm{C}$ during the summer months. Algae were often covered by orange-colored minerals. The outflow water was suboxic (1.3-2.0 $\mathrm{mg} \mathrm{L}^{-1}$ oxygen) at site $\mathrm{O}$ with a slightly acidic $\mathrm{pH}$ of 5.9 ; however water became more oxygenated (6.2-6.9 $\mathrm{mg} \mathrm{L}^{-1}$ oxygen) and had a higher $\mathrm{pH}$ (6.46.5) further downstream (Fig. 2). The increase in oxygen could be caused by both turbulent mixing with air and photosynthetic activities of the algae, and the increase of $\mathrm{pH}$ likely resulted from a combination of $\mathrm{CO}_{2}$ outgassing from the initial anoxic outflow water and draw down of $\mathrm{CO}_{2}$ via algal growth. The water temperature was approximately $14-17^{\circ} \mathrm{C}$ at site $\mathrm{O}$ during sampling. Dissolved iron in the water was primarily in the form of $\mathrm{Fe}(\mathrm{II})$, with maximum concentrations of $3.3 \mathrm{mM}$, and decreased in concentration (to $2.1 \mathrm{mM}$ ) as the water moved downstream towards sites A, B, and C. The other parameters measured did not indicate distinct differences between the sites O, A, B, and C (Eh, 140-180 mV; conductivity, $4.8-4.9 \mathrm{~ms} \mathrm{~cm}^{-1}$; DOC, $3.0-4.5 \mathrm{mg} \mathrm{L}^{-1}$; sulfate concentration, 30-35 mM; Fig. 2). The stream water was also enriched with other metals including $\mathrm{Mn}, \mathrm{Ni}, \mathrm{Zn}$ and $\mathrm{U}$.

In July 2013, we sampled green algae from sites A and B (algae at site $\mathrm{O}$ could not be reached), and brown algae from site C. During a subsequent sampling during August 2013, the algae collected from site B changed in color from green to brown, while algae samples collected from sites $\mathrm{O}$ and A still appeared green. By September 2013, most algae had disappeared; only small amounts of green algae were left at site $\mathrm{O}$ and some brown algae at site $\mathrm{A}$ (Table 1). Sequencing analysis of 18S rRNA gene regions amplified from DNA extracts of green and brown algae showed that all algae had high homologies with Tribonema spp. (T. viride, T. minus, $T$. ulotrichoides, 99.9-100\%; Table S2), a genus of freshwater algae belonging to the class of Xanthophyceae.

Microscopic observations revealed unbranched filamentous algae with a single cell length of $30-50 \mu \mathrm{m}$ and a cell diameter of 8-10 $\mu \mathrm{m}$ (Figs. 3c, d, 4a, b, c). Green algae cells yielded $10-15$ visible chloroplasts which exhibited strong 


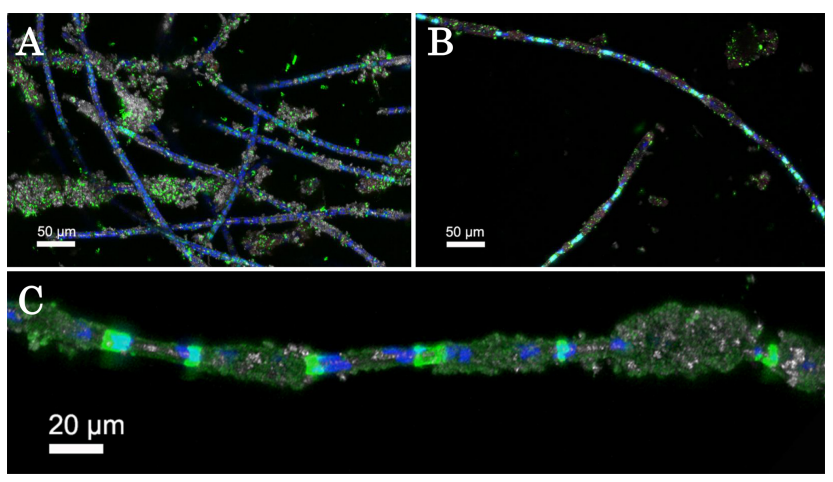

Figure 4. Confocal laser scanning microscopy images of the algaemicrobial communities collected at site $\mathrm{O}$ (outflow) of the stream in September 2013. Maximum intensity projection of the green algae (a) and the brown algae (b) stained with $\mathrm{SYTO}^{\circledR} 9$ were recorded (color allocation: green - nucleic acid stain; blue - autofluorescence of chlorophyll $a$; grey - reflection). Brown algae stained with AALAlexa448 (c) shows glycoconjugates (green), autofluorescence of chlorophyll $a$ (blue), and refection (grey).

autofluorescence, whereas brown algae cells contained only five-seven countable chloroplasts and displayed weaker autofluorescence. The brown algae often showed green autofluorescence under UV-light exposure (data not shown), which likely resulted from flavin-like molecules or luciferin compounds (Tang and Dobbs, 2007). This green autofluorescence was not detected in the green algae, likely due to stronger signals from chloroplasts. According to the cell morphology and number of chloroplasts per cell, the green and brown algae display a high degree of similarity to $T$. viride comparing to T. minus and T. ulotrichoides (Akiyama et al., 1977; Gudleifsson, 1984; H. Wang et al., 2014).

Minerals adhered to, and were distributed in, a regular discontinuous pattern on the surface of the brown algae. In contrast, the surface of the green algae was encrusted with minerals in irregular shape, size and location (Figs. 3c, d, 4a, b). CLSM images using SYTO $^{\circledR} 9$ stain showed that minerals adhered to the surface of both brown and green algae that were colonized by microorganisms (Fig. 4a, b). These microbial cells primarily colonized the minerals attached to the algae surfaces, while a smaller proportion of microbial cells were adhered directly to the algae bodies. Neither stalks of Gallionella nor other characteristic extracellular structures of $\mathrm{FeOB}$ were found on the algae. CLSM images with lectin staining showed that the cell sections in algal filaments were distributed between regularly located Fe-minerals. In addition, algal or bacterial EPS-like glycoconjugates were likely associated with the minerals (Fig. 4c), whereas the amount of EPS could not be quantified or compared between the green and brown algae.

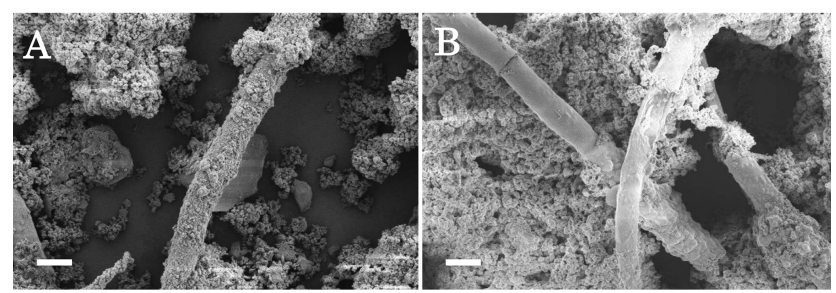

Figure 5. Scanning electron microscopy images of the green algae in site $\mathrm{O}$ (a) and the brown algae in site A (b) taken in September 2013. Scale bars indicate $10 \mu \mathrm{m}$.

\subsection{Component analysis of mineral precipitates on the algae}

Secondary electron (SE) images with EDX analyses showed that sulfur-containing Fe-oxides almost completely covered the surface of the green algae (Figs. 5a, 6a), whereas some areas on the surface of the brown algae were not encrusted (Figs. 5b, 6b). The non-encrusted parts of the brown algae primarily displayed background signal (i.e., Si signal of the sample holder). Weak signals of $\mathrm{C}, \mathrm{Mg}, \mathrm{Ca}$ and $\mathrm{P}$ were also detected by EDX. The elemental composition of Fe-oxides not associated with algae was almost identical to those of the encrusted algae, suggesting mineral composition was not affected by biological activity.

FTIR spectra exhibited signals of ferrihydrite and schwertmannite (Fig. 6c). Their presence was also confirmed by high-resolution SE images. Spherical aggregates with nanoneedles on the surface edges are defining characteristics for schwertmannite (Fig. S1 in the Supplement), while aggregates with no single crystallites are often composed of ferrihydrite (Carlson et al., 2002). The FTIR spectra of minerals on the green algae also showed weak signals of $\mathrm{Si}-\mathrm{O}$ bonding at $1030 \mathrm{~cm}^{-1}$, which might be due to residual clay minerals.

Total extractions of the brown algae collected at site $\mathrm{C}$ revealed that in addition to $\mathrm{Fe}, \mathrm{Mn}, \mathrm{Ni}, \mathrm{Zn}$ and $\mathrm{U}$ accumulated on the algae surface similarly to the underlying sediments at site C (Fig. S2), Fe and U showed even higher concentrations on the surface of the algae in comparison to the sediment (540 $\mathrm{mg}$ of Fe and $910 \mu \mathrm{g}$ of $\mathrm{U}$ in 1 gram of dry weight algae and $390-660 \mathrm{mg}$ of Fe and $90-750 \mu \mathrm{g}$ of $\mathrm{U}$ in 1 gram of dry weight sediment).

\subsection{Elucidating the bacterial community structure associated with algae}

Quantitative PCR detected high gene copy numbers (per gram wet weight algae) for Gallionella-related 16S rRNA with slightly higher numbers for the green algae $\left(1.72 \times 10^{9}\right.$ $7.08 \times 10^{9}$ ) compared to brown algae (Table 1). Similarly, 16S rRNA gene-targeted amplicon pyrosequencing revealed that members of the Gallionellaceae were the dominant bacterial group within these algae-microbial communities 
Table 1. Average 16S rRNA gene copy numbers of Gallionella detected per gram of wet weight algae sampled at sites O, A, B, and C, and at three sampling times in 2013 and measured by quantitative PCR $(n=3, \pm \mathrm{SD})$.

\begin{tabular}{lcccc}
\hline & Site O & Site A & Site B & Site C \\
\hline July 2013 & Not reachable & Green & Green & Brown \\
& & $1.85 \times 10^{9} \pm 1.86 \times 10^{7}$ & $1.72 \times 10^{9} \pm 1.62 \times 10^{8}$ & $0.95 \times 10^{9} \pm 6.66 \times 10^{7}$ \\
\hline August 2013 & Green & Green & Brown & Brown \\
& $6.78 \times 10^{9} \pm 2.36 \times 10^{8}$ & $7.08 \times 10^{9} \pm 3.76 \times 10^{8}$ & $1.45 \times 10^{9} \pm 1.07 \times 10^{8}$ & $1.25 \times 10^{9} \pm 1.62 \times 10^{7}$ \\
\hline September 2013 & Green & Brown & No algae & No algae \\
& $2.25 \times 10^{9} \pm 1.19 \times 10^{7}$ & $1.10 \times 10^{9} \pm 3.47 \times 10^{7}$ & & \\
\hline
\end{tabular}

when comparing both DNA and RNA samples from the green and brown algae collected at all four different sites and all time points (Fig. 7, Table S3). The relative percentage of Gallionellaceae was highest in RNA and DNA extracts of the green algae with 89.4-96.5 and 79.5-96.4\% of the total number of sequence reads, respectively, compared to 70.4-82.9 and 62.7-81.0\% in RNA and DNA extracts of the brown algae. Algal samples collected from sites $\mathrm{O}, \mathrm{A}, \mathrm{B}$, and C during September showed the lowest fraction of Gallionellaceae. The Gallionellaceae group comprised of 2 OTUs (operational taxonomic units) related to the FeOB Gallionella capsiferriformans ES-2 (CP002159) and Sideroxydans lithotrophicus ES-1 (CP001965; Table S3). The relative fraction of OTU-1-related $\mathrm{FeOB}$ was highest at site $\mathrm{O}$, whereas OTU-2-related $\mathrm{FeOB}$ was more abundant downstream at sites A, B, and C. The dendrograms for each DNA and RNA community also showed that the bacterial community structures in site $\mathrm{O}$ were separated from those in other sites (Fig. 7). Other bacterial groups detected with less than $10 \%$ relative abundance were "Candidatus Odyssella" (Alphaproteobacteria), Actinomycetales (Actinobacteria), Desulfobulbaceae, and Geobacteraceae (Deltaproteobacteria). Triplicate extractions of DNA and RNA from the brown algae collected at site $\mathrm{C}$ in August showed little variation between bacterial community structures (Fig. 7), which allows for the identification of a representative algae surface-associated microbial community in this metalcontaminated site. The brown algae were colonized by a higher diversity of bacterial groups than the green algae, showing higher average Gini-Simpson index values ( 0.862 in RNA and 0.884 in DNA) than those of the green algae (0.641 in RNA and 0.645 in DNA). Interestingly, some of the sequences detected from the microorganisms adhered to the brown algae surface were identified as putative predators of algae, such as "Candidatus Odyssella" (intracellular parasite of Acanthamoeba, up to 8.1 and $6.0 \%$ of OTUs in RNA and DNA extracts) and Cystobacteraceae (Myxobacteria, 2.0 and $0.2 \%$ in RNA and DNA extracts).

\section{Discussion}

Members of the genus Tribonema are known as common freshwater algae (Machova et al., 2008; H. Wang et al., 2014). Tribonema species have been detected in other metalrich and acidic freshwater environments such as acidic brown water streams $(\mathrm{pH}<4)$ in New Zealand (Collier and Winterbourn, 1990), acidic coal mine drainage-contaminated sites (pH 2.6-6.0; Winterbourn et al., 2000), as well as acidic rivers ( $\mathrm{pH}$ 2.7-4.0) with iron-rich ocherous deposits of schwertmannite-like Fe-minerals on algal surfaces (CourtinNomade et al., 2005), suggesting their tolerance to high concentrations of metals and low $\mathrm{pH}$. In this study, T. viride colonized metal-rich ( $\mathrm{Fe}, \mathrm{Mn}, \mathrm{Ni}, \mathrm{Zn}$ and $\mathrm{U}$ ) and less acidic (pH 5.9 to 6.5) mine-water outflow which showed variation in geochemistry over time and along the flow paths from site $\mathrm{O}$ to $\mathrm{C}$. The algae ostensibly changed its color from green to brown and disappeared completely from sites $\mathrm{B}$ and $\mathrm{C}$ at the end of the summer. The change in algae color occurred simultaneously with the loss of active chloroplasts per cell, as observed via CLSM imaging. These results correspond with lower numbers of sequences originating from chloroplasts based on sequences analysis. The encrustation with Fe-minerals presumably inhibits algal photosynthetic activities and may be an underlying cause for the disappearance of Tribonema at the end of the summer when light intensity diminished. The observed water temperatures (14$17^{\circ} \mathrm{C}$ ) may have also contributed to the decline in algae numbers, since optimal growth temperatures of two genera of Tribonema are higher (T. fonticolum, $19-27^{\circ} \mathrm{C} ;$ T. monochloron, 15.5-23.5 ${ }^{\circ} \mathrm{C}$; Machova et al., 2008); however T. viride has been detected in lake water with low temperatures $\left(0-5.6^{\circ} \mathrm{C}\right.$; Vinocur and Izaguirre, 1994).

Deposition of Fe-minerals and colonization of iron bacteria on Tribonema was reported more than 70 years ago (Chapman, 1941), but identification of the deposited minerals, the $\mathrm{FeOB}$, and their interaction with the alga has not been characterized in detail. A symbiotic relationship has been suggested in which microbes living on the surface of Tribonema form ferric carbonate, which controls water $\mathrm{pH}$ and acts as local buffer for the algae. We could not detect 
A

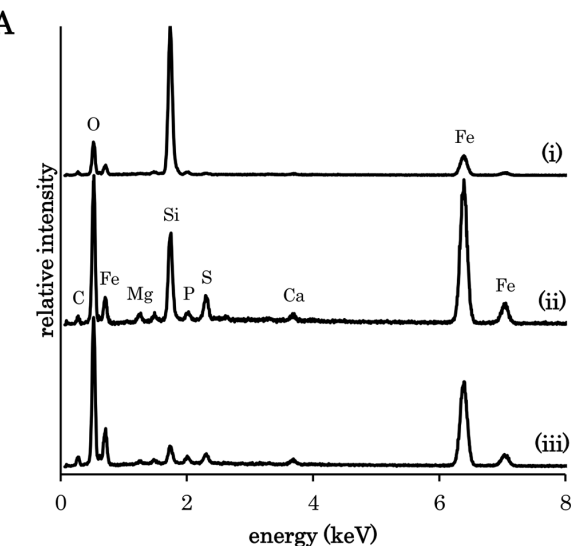

C

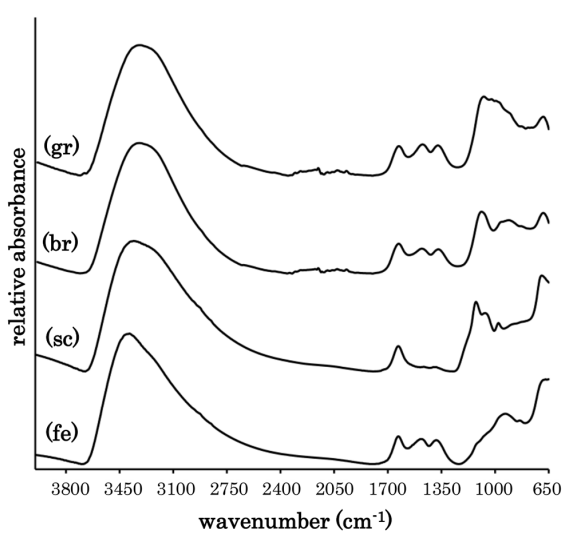

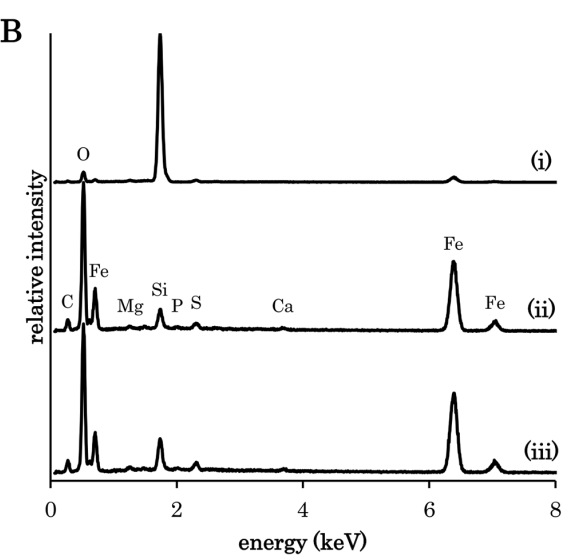

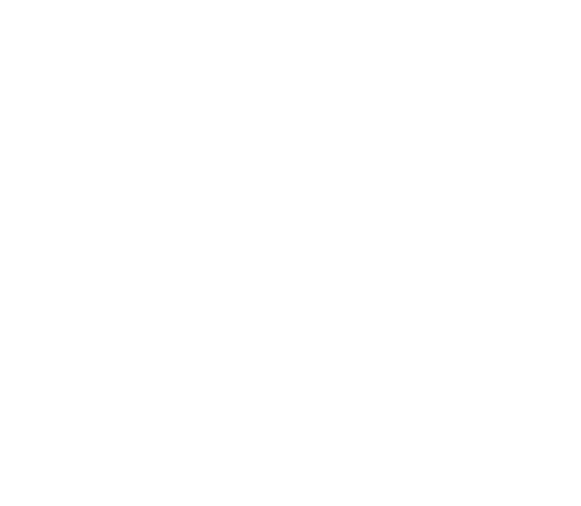

Figure 6. EDX and FTIR spectra of minerals precipitated around the algae. EDX spectra of minerals around the green algae (a) and the brown algae (b) were recorded on the non-encrusted algal surface (i), the encrusted algal surface (ii) and Fe-oxides which were not connected to the algae (iii). FTIR spectra of Fe-oxides (c) were recorded on the green algae (gr) and the brown algae (br), when compared with spectra of schwertmannite (sc) and ferrihydrite (fe) as references.

ferric carbonates on Tribonema; however, poorly crystalline iron minerals, ferrihydrite and schwertmannite, that are also present in the underlying sediments in addition to goethite, were detected (Johnson et al., 2014). These iron minerals have a high reactive surface area for metal(loid) uptake, and particularly As and $\mathrm{Zn}$ appear to be associated with these minerals in the sediments (Johnson et al., 2014). Brown algae showed similar metal(loid) uptake to the sediments collected at the outflow downstream to site $\mathrm{C}$ with even higher concentrations for $\mathrm{Fe}$ and $\mathrm{U}$, suggesting a high affinity of Tribonema to these compounds. Thus, these iron coatings could also act as buffers to help prevent the plant from taking up these heavy metals, similar to the mechanism suggested to aid in the protection from root plaque (Tripathi et al., 2014 and references therein). However, since there was no pristine system without metal load around our study site, we could not assess the effects of heavy metals on development of the algae-bacteria-mineral communities.

Our microscopic investigation did not reveal a preferential colonization of microbes on the algal surface but on the minerals. According to both pyrosequencing and qPCR results, microaerophilic Gallionella-related FeOB were the dominant colonizers on Tribonema which might be due to the presence of large populations of Gallionella sp. (29-58\% of the total bacterial community) in the outflow water, reaching cell numbers of $10^{5}$ to $10^{6}$ cells per $\mathrm{mL}$ water (Fabisch et al., 2015). These bacteria seem to be able to cope with the high levels of oxygen produced during photosynthesis, but these oxygen concentrations may be lower within the EPS matrix and ocher deposits. G.capsiferriformans-related $\mathrm{FeOB}$ predominated at the outflow site, whereas $S$. lithotrophicusrelated $\mathrm{FeOB}$ dominated algae further downstream, which can be explained by differences in the water geochemistry such as $\mathrm{pH}$ or heavy metal concentrations. Based on genome information, G. capsiferriformans ES-2 should be more resistant to heavy metals than S. lithotrophicus ES-1 (Emerson et al., 2013) and thus should dominate the outflow site which showed the highest metal loads in the water. Unfortunately, we could not link the dominance of these species with the heavy metals precipitated on the algae due to shortage of the present sample amount for ICP-MS/OES.

16S rRNA gene copy numbers of Gallionella on the algae surfaces (Table 1) were much higher than numbers found in the sediments of the stream $\left(3.1 \times 10^{8}\right.$ copies per gram 

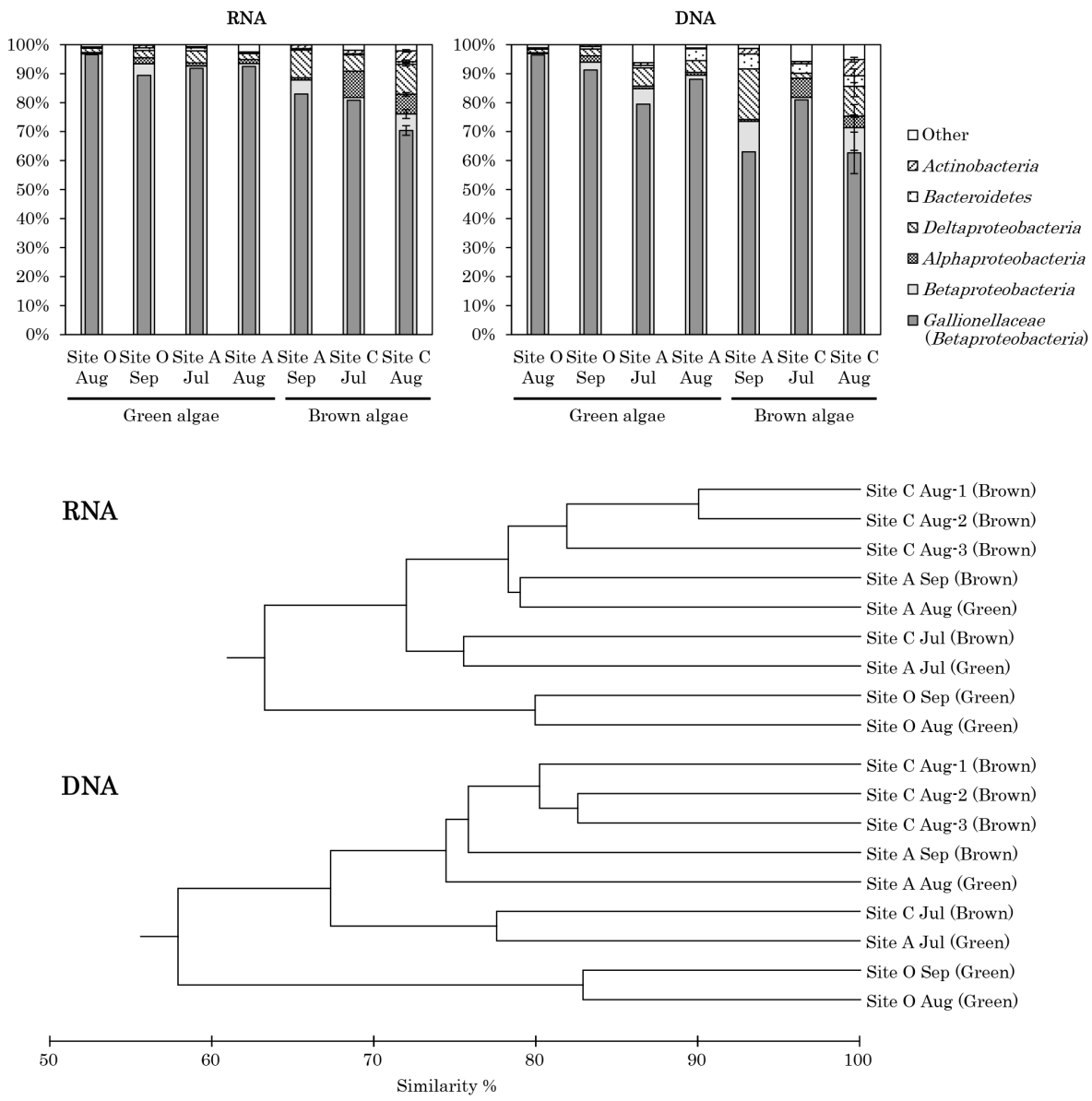

Figure 7. Bacterial community compositions obtained from algal samples detected by 16S rRNA gene-targeted amplicon pyrosequencing (above) and dendrograms indicating similarities of RNA and DNA compositions (below). Calculations of the bacterial populations were based on the total numbers of OTUs associated with phylotypes of sequenced representatives at the phylum level, or class level for Proteobacteria. Percentages of Gallionellaceae (Betaproteobacteria) were also shown. ( $n=1$; Site C Aug, $n=3$, error bars indicate SD).

wet weight sediment; Fabisch et al., 2015). The high relative RNA-derived fraction of Gallionellaceae suggested not only passive or active colonization of the algal surface, but also participation in Fe-oxidation followed by ferrihydrite and schwertmannite formation. Gallionella-related $\mathrm{FeOB}$ appeared to be more abundant and active on the green algae, which indicates higher Fe-oxidizing activity on the surface of green algae. The surface of photosynthetic algae is presumable a highly oxygen-saturated environment, and the occurrence of neutrophilic microaerophilic $\mathrm{FeOB}$ under such conditions has not been reported before to the best of our knowledge. However, it is possible that at night the oxygen level go to a much lower level allowing an opportunity for $\mathrm{FeOB}$ to grow under low oxygen. In water treatment systems and dewatering wells in opencast mines, Gallionella have also been reported to grow at surprisingly high oxygen concentrations at the low temperature of $13{ }^{\circ} \mathrm{C}$ or even higher which slows down abiotic Fe(II)-oxidation (de Vet et al., 2011; J. Wang et al., 2014).
In an $\mathrm{Fe}$ (II)-rich and oxygenated environment, bacteria potentially face the problem of highly reactive oxygen species due to the reaction of hydrogen peroxide with $\mathrm{Fe}$ (II) (Imlay, 2008). Both G. capsiferriformans ES-2 and S. lithotrophicus ES-1 were reported to encode enzymes that presumably act as catalase or peroxidase to prevent production of reactive oxygen species (Emerson et al., 2013). Most bacteria associated with the Fe-minerals on algae surfaces were also localized to areas where EPS-like glycoconjugates were detected. EPS forms a suitable microenvironment for microbial Fe-oxidation due to its ability to bind dissolved Fe(II) resulting from the negatively charged EPS matrix. This activity leads to the inhibition of chemical Fe-oxidation by lowering the availability of $\mathrm{Fe}(\mathrm{II})$ (Neubauer et al., 2002; Jiao et al., 2010; Roth et al., 2000). In addition, the EPS can prevent bacterial cells from being encrusted with insoluble Fe(III)oxides (Neubauer et al., 2002; Hedrich et al., 2011a; Schädler et al., 2009). Unfortunately, with the methods used, we could not determine if the EPS-like matrix on the algae was pro- 
duced by the alga or by bacteria. Tribonema is known to produce EPS mainly composed of glucans and xylans (Cleare and Percival, 1972); however, based on genome sequencing, both G. capsiferriformas ES-2 and S. lithotrophicus ES-1 are predicted to also produce EPS (Emerson et al., 2013). In an effort to prevent encrustation, other Gallionella species form long stalks which are mainly composed of polysaccharides and long-chain saturated aliphatic compounds during Fe(II)oxidation with the purpose of deposition of Fe-oxides apart from the cells (Chan et al., 2011; Suzuki et al., 2011; Fabisch et al., 2015; Picard et al., 2015). Stalk-forming Gallionella have been isolated in sediment environments, but not on the surface of algae, thus implicating an important role of EPS in microbial $\mathrm{Fe}$-oxidation by the algae-associated bacteria. Our results cannot exclude the possibility that FeOB utilize algal EPS as an organic carbon source, whereas G. capsiferriformans and S. lithotrophicus were reported to be unable to grow heterotrophically (Emerson et al., 2013). The variations in color of the Tribonema species were accompanied with a variation in encrustation patterns. The green Tribonema was fully encrusted, whereas the brown Tribonema showed an irregular encrustation pattern. Although Tribonema appears to be adapted to high metal loads, excess encrustations with $\mathrm{Fe}$ minerals should be detrimental due to inhibition of photosynthesis and decreased access to nutrients. The lower number of chloroplasts pointed to decreased photosynthetic activity of the brown Tribonema. The discontinuous encrustation might be caused by intercalary growth of the filamentous algae, which occurs by generating $\mathrm{H}$-shaped parts in the middle of each cell (Smith, 1938). Intercalary growth was confirmed by CLSM images with lectin staining which showed algal cell sections alternating with Fe-minerals. The new cell sections were thin with only a few chloroplasts, suggesting that energy was used primarily for elongation. Thus, intercalary growth could be interpreted as a defense strategy during later stages of encrustation when photosynthetic activity diminishes due to surface coverage by Fe-precipitates and to provide the algae with new uncovered cell surfaces.

Production of EPS as a shunt mechanism should decline if less carbon is fixed during photosynthesis (Wotton, 2004) which provides a potential link between EPS production and Gallionella colonization. Brown algae contained fewer chloroplasts, suggesting reduced photosynthetic activity and EPS production which might be linked to a decrease in $\mathrm{Gal}$ lionella cell number and Fe(II) oxidation on the algae surface. This study showed higher microbial diversity on the surface of brown Tribonema when lower numbers of Gallionella were detected. Some putative predators of algae, such as "Candidatus Odyssella" and Cystobacteraceae were also identified on the surface of the brown Tribonema. These predators colonize algae in order to consume material released upon cell lysis as a natural senescence process or under stress conditions (Levy et al., 2009). Algal EPS has been shown to function as a cell defense mechanism to protect cells from colonization of predators or pathogens (Steinberg et al., 1997), thus a reduced rate of EPS formation may lead to predator colonization.

\section{Summary and conclusion}

Filamentous algae (Tribonema sp.) were observed in the metal-contaminated groundwater outflow in the former Ronneburg uranium mining district, suggesting the algae has a tolerance to high metal concentrations and metal deposits. Cells of green algae were fully encrusted with $\mathrm{Fe}$-oxides. The Fe-precipitates on the algae surfaces were predominantly colonized by Gallionella-related FeOB. Gallionella-related $\mathrm{FeOB}$ were abundant in the stream water and these bacteria appeared to be actively involved in Fe(II) oxidation. Thus, both sunlight and $\mathrm{Fe}$ (II) served as energy sources for primary producers in this slightly acidic stream, promoting complex microbial interactions in the ocher deposits on the algal cells. EPS-like polymeric matrices, likely produced as a shunt for carbon during photosynthesis, provided a suitable microenvironment for the microaerophilic $\mathrm{FeOB}$ due to its high affinity for metal(loid)s and reduced oxygen diffusion. However, excess deposition of Fe-oxides appeared to be detrimental to photosynthetic activities, forcing intercalary elongation of the filaments. This defense response caused discontinuous deposition patterns of Fe-oxides as observed on the browncolored algae which showed a lower number of chloroplasts. The reduced EPS production could have favored growth of algal predators on the brown algae and together with ocher deposition contributed to algal decline.

\section{The Supplement related to this article is available online at doi:10.5194/bg-12-5277-2015-supplement.}

Author contributions. J. F. Mori and K. Küsel designed the experiments and J. F. Mori performed the experiments. T. R. Neu conducted CLSM imaging analysis. S. Lu carried out sampling and microscopic analysis with J. F. Mori. M. Händel and K. U. Totsche performed SEM-EDX and FTIR analysis. J. F. Mori prepared the manuscript with contributions from all co-authors.

Acknowledgements. The authors thank the graduate research training group "Alternation and element mobility at the microbemineral interface" (GRK 1257), which is part of the Jena School for Microbial Communication (JSMC) and funded by the Deutsche Forschungsgemeinschaft (DFG). We would also like to thank Denise M. Akob and Georg Büchel for help during sampling. We appreciate Martina Herrmann for sequence analysis, Maren Sickinger for qPCR works, Dirk Merten for ICP measurements, Gundula Rudolph for DOC analysis, Steffen Kolb, Juanjuan Wang, and Maria Fabisch for helpful discussions, and Rebecca Cooper for manuscript proofreading. 
Edited by: Z. Jia

\section{References}

Akiyama, M., Ioriya, T., Imahori, K., Kasaki, H., Kumamoto, S., Kobayashi, H., Takahashi, E., Tsumura, K., Hirano, M., and Hirose, H.: Illustrations of the Japanese Fresh-Water Algae, Uchidarokakuho Publishing Company, Limited, 1977.

Azam, F.: Microbial control of oceanic carbon flux: the plot thickens, Science, 280, 694-695, 1998.

Bray, J. R. and Curtis, J. T.: An ordination of the upland forest communities of southern Wisconsin, Ecol. Monogr., 27, 325-349, 1957.

Cantonati, M. and Lowe, R. L.: Lake benthic algae: toward an understanding of their ecology, Freshwater, 33, 475-486, 2014.

Carlson, L., Bigham, J. M., Schwertmann, U., Kyek, A., and Wagner, F.: Scavenging of As from acid mine drainage by schwertmannite and ferrihydrite: a comparison with synthetic analogues, Environ. Sci. Technol., 36, 1712-1719, doi:10.1021/es0110271, 2002.

Chan, C. S., Fakra, S. C., Emerson, D., Fleming, E. J., and Edwards, K. J.: Lithotrophic iron-oxidizing bacteria produce organic stalks to control mineral growth: implications for biosignature formation, ISME J., 5, 717-727, doi:10.1038/ismej.2010.173, 2011.

Chapman, V. J.: An introduction to the study of Algae, Cambrige University Press, 387 pp., 1941.

Cleare, M. and Percival, E.: Carbohydrates of the fresh water alga Tribonema aequale. I. Low molecular weight and polysaccharides, Brit. Phycol. J., 7, 185-193, doi:10.1080/00071617200650201, 1972.

Cole, J. J.: Interactions between bacteria and algae in aquatic ecosystems, Annu. Rev. Ecol. Syst., 13, 291-3-14, 1982.

Collier, K. and Winterbourn, M.: Structure of epilithon in some acidic and circumneutral streams in South Westland, New Zealand, New Zealand Natural Sciences, 17, 1-11, 1990.

Colmer, A. R. and Hinkle, M.: The role of microorganisms in acid mine drainage: a preliminary report, Science, 106, 253-256, 1947.

Courtin-Nomade, A., Grosbois, C., Bril, H., and Roussel, C.: Spatial variability of arsenic in some iron-rich deposits generated by acid mine drainage, Appl. Geochem., 20, 383-396, doi:10.1016/j.apgeochem.2004.08.002, 2005.

Das, B. K., Roy, A., Koschorreck, M., Mandal, S. M., WendtPotthoff, K., and Bhattacharya, J.: Occurrence and role of algae and fungi in acid mine drainage environment with special reference to metals and sulfate immobilization, Water Res., 43, 883894, doi:10.1016/j.watres.2008.11.046, 2009.

de Vet, W. W. J. M., Dinkla, I. J. T., Rietveld, L. C., and van Loosdrecht, M. C. M.: Biological iron oxidation by Gallionella spp. in drinking water production under fully aerated conditions, Water Res., 45, 5389-5398, doi:10.1016/j.watres.2011.07.028, 2011.

Dorigo, U., Berard, A., and Humbert, J. F.: Comparison of eukaryotic phytobenthic community composition in a polluted river by partial 18S rRNA gene cloning and sequencing, Microb. Ecol., 44, 372-380, doi:10.1007/s00248-002-2024-x, 2002.

Emerson, D. and Moyer, C.: Isolation and characterization of novel iron-oxidizing bacteria that grow at circumneutral pH, Appl. Environ. Microb., 63, 4784-4792, 1997.

Emerson, D. and Weiss, J. V.: Bacterial iron oxidation in circumneutral freshwater habitats: findings from the field and the laboratory, Geomicrobiol. J., 21, 405-414, 2004.

Emerson, D., Weiss, J. V., and Megonigal, J. P.: Iron-oxidizing bacteria are associated with ferric hydroxide precipitates (Fe-plaque) on the roots of wetland plants, Appl. Environ. Microb., 65, 27582761, 1999.

Emerson, D., Field, E., Chertkov, O., Davenport, K., Goodwin, L., Munk, C., Nolan, M., and Woyke, T.: Comparative genomics of freshwater Fe-oxidizing bacteria: implications for physiology, ecology, and systematics, Front. Microbiol., 4, 254, doi:10.3389/fmicb.2013.00254, 2013.

Euringer, K. and Lueders, T.: An optimised PCR/T-RFLP fingerprinting approach for the investigation of protistan communities in groundwater environments, J. Microbiol. Meth., 75, 262-268, doi:10.1016/j.mimet.2008.06.012, 2008.

Fabisch, M., Beulig, F., Akob, D. M., and Küsel, K.: Surprising abundance of Gallionella-related iron oxidizers in creek sediments at $\mathrm{pH} 4.4$ or at high heavy metal concentrations, Front. Microbiol., 4, 390, doi:10.3389/fmicb.2013.00390, 2013.

Fabisch, M., Freyer, G., Johnson, C. A., Büchel, G., Akob, D. M., Neu, T. R., and Küsel, K.: Dominance of "Gallionella capsiferriformans" and heavy metal association with Gallionella-like stalks in metal-rich pH 6 mine water discharge, Geobiology, in press, 2015.

Fisher, M., Zamir, A., and Pick, U.: Iron uptake by the halotolerant alga Dunaliella is mediated by a plasma membrane transferrin, J. Biol. Chem., 273, 17553-17558, 1998.

Foster, P. L.: Copper exclusion as a mechanism of heavy metal tolerance in a green alga, Nature, 269, 322-323, 1977.

Foster, P. L.: Metal resistances of Chlorophyta from rivers polluted by heavy metals, Freshwater Biol., 12, 4-1-61, 1982.

Gebühr, C., Pohlon, E., Schmidt, A., and Küsel, K.: Development of microalgae communities in the phytotelmata of allochthonous populations of Sarracenia purpurea (Sarraceniaceae), Plant Biol., 8, 849-860, 2006.

Geesey, G., Mutch, R., Costerton, J. T., and Green, R.: Sessile bacteria: an important component of the microbial population in small mountain streams, Limnol. Oceanogr., 23, 1214-1223, 1978.

Greene, B., McPherson, R., and Darnall, D.: Algal sorbents for selective metal ion recovery, in: Metals Speciation, Separation, and Recovery, Lewis Publishers Chelsea, MI, 315-338, 1987.

Gudleifsson, B. E.: Tribonema viride (Xanthophyta) on cultivated grassland during winter and spring, Acta Botanica Islandica, 7, 27-30, 1984

Haack, T. K. and McFeters, G. A.: Microbial dynamics of an epilithic mat community in a high alpine stream, Appl. Environ. Microb., 43, 702-707, 1982.

Hallberg, K. B., Coupland, K., Kimura, S., and Johnson, D. B.: Macroscopic streamer growths in acidic, metal-rich mine waters in north wales consist of novel and remarkably simple bacterial communities, Appl. Environ. Microb., 72, 2022-2030, doi:10.1128/aem.72.3.2022-2030.2006, 2006.

Hanert, H. H.: The genus Gallionella, in: The prokaryotes, Springer Verlag, New York, 990-995, 2006. 
Hedrich, S., Lunsdorf, H., Keeberg, R., Heide, G., Seifert, J., and Schlomann, M.: Schwertmannite formation adjacent to bacterial cells in a mine water treatment plant and in pure cultures of Ferrovum myxofaciens, Environ. Sci. Technol., 45, 7685-7692, doi:10.1021/es201564g, 2011a.

Hedrich, S., Schlomann, M., and Johnson, D. B.: The ironoxidizing proteobacteria, Microbiology, 157, 1551-1564, doi:10.1099/mic.0.045344-0, 2011b.

Hegler, F., Lösekann-Behrens, T., Hanselmann, K., Behrens, S., and Kappler, A.: Influence of seasonal and geochemical changes on the geomicrobiology of an iron carbonate mineral water spring, Appl. Environ. Microb., 78, 7185-7196, doi:10.1128/aem.01440-12, 2012.

Heinzel, E., Janneck, E., Glombitza, F., Schlömann, M., and Seifert, J.: Population dynamics of iron-oxidizing communities in pilot plants for the treatment of acid mine waters, Environ. Sci. Technol., 43, 6138-6144, 2009.

Imlay, J. A.: Cellular defenses against superoxide and hydrogen peroxide, Annu. Rev. Biochem., 77, 755-776, doi:10.1146/annurev.biochem.77.061606.161055, 2008.

Jiao, Y., Cody, G. D., Harding, A. K., Wilmes, P., Schrenk, M., Wheeler, K. E., Banfield, J. F., and Thelen, M. P.: Characterization of extracellular polymeric substances from acidophilic microbial biofilms, Appl. Environ. Microb., 76, 2916-2922, doi:10.1128/aem.02289-09, 2010.

Johnson, C. A., Freyer, G., Fabisch, M., Caraballo, M. A., Küsel, K., and Hochella, M. F.: Observations and assessment of iron oxide and green rust nanoparticles in metal-polluted mine drainage within a steep redox gradient, Environ. Chem., 11, 377-391, doi:10.1071/EN13184, 2014.

Johnson, D. B. and Hallberg, K. B.: Carbon, iron and sulfur metabolism in acidophilic micro-organisms, Adv. Microb. Physiol., 54, 201-255, doi:10.1016/s0065-2911(08)00003-9, 2009.

Johnsongreen, P. C. and Crowder, A. A.: Iron-oxide deposition on axenic and non-axenic roots of rice seedlings (Oryza sativa L.), J. Plant Nutr., 14, 375-386, doi:10.1080/01904169109364209, 1991.

Kappler, A. and Straub, K. L.: Geomicrobiological cycling of iron, Rev. Mineral. Geochem., 59, 85-108, 2005.

Kozubal, M. A., Macur, R. E., Jay, Z. J., Beam, J. P., Malfatti, S. A., Tringe, S. G., Kocar, B. D., Borch, T., and Inskeep, W. P.: Microbial iron cycling in acidic geothermal springs of Yellowstone National Park: integrating molecular surveys, geochemical processes, and isolation of novel Fe-active microorganisms, Front. Microbiol., 3, 109, doi:10.3389/fmicb.2012.00109, 2012.

Leduc, L. G. and Ferroni, G. D.: The chemolithotrophic bacterium Thibacillus ferrooxidans, FEMS Microbiol. Rev., 14, 103-119, 1994.

Levy, J., Stauber, J. L., Wakelin, S. A., and Jolley, D. F.: The effect of bacteria on the sensitivity of microalgae to copper in laboratory bioassays, Chemosphere, 74, 1266-1274, doi:10.1016/j.chemosphere.2008.10.049, 2009.

Liu, H. and Buskey, E. J.: Hypersalinity enhances the production of extracellular polymeric substance (EPS) in the Texas brown tide alga, Aureoumbra lagunensis (Pelagophyceae), J. Phycol., 36, 71-77, 2000.

López-Archilla, A. I., Marin, I., and Amils, R.: Microbial community composition and ecology of an acidic aquatic environment: the Tinto River, Spain, Microb. Ecol., 41, 20-35, 2001.
Lüdecke, C., Reiche, M., Eusterhues, K., Nietzsche, S., and Küsel, K.: Acid-tolerant microaerophilic Fe(II)-oxidizing bacteria promote Fe(III)-accumulation in a fen, Environ. Microbiol., 12, 2814-2825, doi:10.1111/j.1462-2920.2010.02251.x, 2010.

Machova, K., Elster, J., and Adamec, L.: Xanthophyceaen assemblages during winter-spring flood: autecology and ecophysiology of Tribonema fonticolum and T. monochloron, Hydrobiologia, 600, 155-168, doi:10.1007/s10750-007-9228-5, 2008.

Malik, A.: Metal bioremediation through growing cells, Environ. Int., 30, 261-278, 2004.

Neu, T. R., Swerhone, G. D., and Lawrence, J. R.: Assessment of lectin-binding analysis for in situ detection of glycoconjugates in biofilm systems, Microbiology, 147, 299-313, 2001.

Neubauer, S. C., Emerson, D., and Megonigal, J. P.: Life at the energetic edge: kinetics of circumneutral iron oxidation by lithotrophic iron-oxidizing bacteria isolated from the wetlandplant rhizosphere, Appl. Environ. Microb., 68, 3988-3995, doi:10.1128/aem.68.8.3988-3995.2002, 2002.

Peine, A., Tritschler, A., Küsel, K., and Peiffer, S.: Electron flow in an iron-rich acidic sediment - evidence for an acidity-driven iron cycle, Limnol. Oceanogr., 45, 1077-1087, 2000.

Picard, A., Kappler, A., Schmid, G., Quaroni, L., and Obst, M.: Experimental diagenesis of organo-mineral structures formed by microaerophilic Fe(II)-oxidizing bacteria, Nat. Comm., 6, 6277, doi:10.1038/ncomms7277, 2015.

Reed, R. and Gadd, G.: Metal tolerance in eukaryotic and prokaryotic algae, in: Heavy Metal Tolerance in Plants: Evolutionary Aspects, CRC press, Boca Raton, FL, 105-118, 1989.

Roth, R. I., Panter, S. S., Zegna, A. I., and Levin, J.: Bacterial endotoxin (lipopolysaccharide) stimulates the rate of iron oxidation, J. Endotoxin Res., 6, 313-319, 2000.

Rowe, O. F., Sanchez-Espana, J., Hallberg, K. B., and Johnson, D. B.: Microbial communities and geochemical dynamics in an extremely acidic, metal-rich stream at an abandoned sulfide mine (Huelva, Spain) underpinned by two functional primary production systems, Environ. Microbiol., 9, 1761-1771, doi:10.1111/j.1462-2920.2007.01294.x, 2007.

Schädler, S., Burkhardt, C., Hegler, F., Straub, K. L., Miot, J., Benzerara, K., and Kappler, A.: Formation of cell-ironmineral aggregates by phototrophic and nitrate-reducing anaerobic Fe(II)-oxidizing bacteria, Geomicrobiol. J., 26, 93-103, doi:10.1080/01490450802660573, 2009.

Schloss, P. D., Westcott, S. L., Ryabin, T., Hall, J. R., Hartmann, M., Hollister, E. B., Lesniewski, R. A., Oakley, B. B., Parks, D. H., and Robinson, C. J.: Introducing mothur: open-source, platformindependent, community-supported software for describing and comparing microbial communities, Appl. Environ. Microb., 75, 7537-7541, 2009.

Sengbusch, P. V. and Müller, U.: Distribution of glycoconjugates at algal cell surfaces as monitored by FITC-conjugated lectins. Studies on selected species from Cyanophyta, Pyrrhophyta, Raphidophyta, Euglenophyta, Chromophyta, and Chlorophyta, Protoplasma, 114, 103-113, 1983.

Senko, J. M., Wanjugi, P., Lucas, M., Bruns, M. A., and Burgos, W. D.: Characterization of $\mathrm{Fe}(\mathrm{II})$ oxidizing bacterial activities and communities at two acidic Appalachian coalmine drainageimpacted sites, ISME J., 2, 1134-1145, 2008.

Smith, G. M.: Cryptogamic Botany, Vol. 1, Algae and Fungi, McGraw-Hill, New York, 169-170, 1938. 
Steinberg, P. D., Schneider, R., and Kjelleberg, S.: Chemical defenses of seaweeds against microbial colonization, Biodegradation, 8, 211-220, doi:10.1023/a:1008236901790, 1997.

Stevenson, R. J., Bothwell, M. L., Lowe, R. L., and Thorp, J. H.: Algal ecology: Freshwater Benthic Ecosystem, Academic press, San Diego, 1996.

Suzuki, T., Hashimoto, H., Matsumoto, N., Furutani, M., Kunoh, H., and Takada, J.: Nanometer-scale visualization and strucural analysis of the inorganic/organic hybrid structures of Gallionella ferruginea twisted stalks, Appl. Environ. Microb., 77, 2877-2881, doi:10.1128/aem.02867-10, 2011.

Tabatabai, M. A.: A rapid method for determination of sulfate in water samples, Environ. Lett., 7, 237-243, 1974.

Tamura, H., Goto, K., Yotsuyan, T., and Nagayama, M.: Spectrophotometric determination of iron(II) with 1,10phenanthroline in presence of large amounts of iron(III), Talanta, 21, 314-318, doi:10.1016/0039-9140(74)80012-3, 1974.

Tang, Y. Z. and Dobbs, F. C.: Green autofluorescence in dinoflagellates, diatoms, and other microalgae and its implications for vital staining and morphological studies, Appl. Environ. Microb., 73, 2306-2313, doi:10.1128/aem.01741-06, 2007.

Transeau, E. N.: The periodicity of freshwater algae, Am. J. Bot., 3, 121-133, 1916.

Tripathi, R. D., Tripathi, P., Dwivedi, S., Kumar, A., Mishra, A., Chauhan, P. S., Norton, G. J., and Nautiyal, C. S.: Roles for root iron plaque in sequestration and uptake of heavy metals and metalloids in aquatic and wetland plants, Metallomics, 6, 17891800, doi:10.1039/c4mt00111g, 2014.

Trouwborst, R. E., Johnston, A., Koch, G., Luther, G. W., and Pierson, B. K.: Biogeochemistry of $\mathrm{Fe}(\mathrm{II})$ oxidation in a photosynthetic microbial mat: implications for Precambrian Fe(II) oxidation, Geochim. Cosmochim. Acta, 71, 4629-4643, doi:10.1016/j.gca.2007.07.018, 2007.
Tyson, G. W., Chapman, J., Hugenholtz, P., Allen, E. E., Ram, R. J., Richardson, P. M., Solovyev, V. V., Rubin, E. M., Rokhsar, D. S., and Banfield, J. F.: Community structure and metabolism through reconstruction of microbial genomes from the environment, Nature, 428, 37-43, doi:10.1038/nature02340, 2004.

Vinocur, A. and Izaguirre, I.: Freshwater algae (excluding Cyanophyceae) from nine lakes and pools of Hope Bay, Antarctic Peninsula, Antarct. Sci., 6, 483-490, 1994.

Wang, H., Ji, B., Wang, J., Guo, F., Zhou, W., Gao, L., and Liu, T.: Growth and biochemical composition of filamentous microalgae Tribonema sp. as potential biofuel feedstock, Bioproc. Biosyst. Eng., 37, 2607-2613, 2014.

Wang, J., Sickinger, M., Ciobota, V., Herrmann, M., Rasch, Helfried, Rösch, P., Popp, J., and Küsel, K.: Revealing the microbial community structure of clogging materials in dewatering wells differing in physico-chemical parameters in an open-cast mining area, Water Res., 63, 222-233, doi:10.1016/j.watres.2014.06.021, 2014.

Warner, R. W.: Distribution of biota in a stream polluted by acid mine-drainage, Ohio J. Sci., 71, 202-215, 1971.

Wiegert, R. G. and Mitchell, R.: Ecology of Yellowstone thermal effluent systems: intersects of blue-green algae, grazing flies (Paracoenia, Ephydridae) and water mites (Partnuniella, Hydrachnellae), Hydrobiologia, 41, 251-271, 1973.

Winterbourn, M. J., McDiffett, W. F., and Eppley, S. J.: Aluminium and iron burdens of aquatic biota in New Zealand streams contaminated by acid mine drainage: effects of trophic level, Sci. Total Environ., 254, 45-54, doi:10.1016/s0048-9697(00)00437x, 2000

Wotton, R. S.: The utiquity and many roles of exopolymers (EPS) in aquatic systems, Sci. Mar., 68, 13-21, 2004.

Yu, Q., Matheickal, J. T., Yin, P., and Kaewsarn, P.: Heavy metal uptake capacities of common marine macro algal biomass, Water Res., 33, 1534-1537, 1999. 